\title{
ХРОНИКА
}

УДК 549.283

\section{Achievements in Nanomineralogy}

\section{B.M. Osovetsky}

Perm State University, Nanomineralogy Sector, 15, Bukireva Str., Perm, 614990, Russia. E-mail: opal@psu.ru

(Paper was submitted 10 April 2017)

The results of investigations in the field of nanomineralogy obtained by the Nanomineralogy Sector staff during 5 years (2012-2016) are presented. These include results of researches with the application of high-resolution electron microscopy with microprobe analysis and experimental data. The study objects were unusual grains of placer gold of the Urals, Siberia (Russia), Kazakhstan, and the Yukon Territory (Canada). It is concluded that there are nanogold aggregation processes which lead to the formation of globular and "new" gold. These processes may be used in modern technologies of gold extraction.

Key words: nanogold, electron microscopy, aggregation, technology. DOI: 10.17072/psu.geol.16.2.193

In November 2011, the Nanomineralogy Sector of Perm State University was founded. One of the tasks set before this new scientific structure was the development of fundamental researches in the field of nanomineralogy. They include the morphological description of fine gold, platinum and diamond particles under the scanning electron microscope JSM $7500 \mathrm{~F}$ (Jeol) in a very broad range of magnification (from 25 to 600,000) and microprobe analysis (ED-spectrometer INCA 350 Energy).

Nanogold. The point is that the methods of high-resolution electron microscopy have recently made a significant progress in the study of gold nanomineralogy (Hough et al., 2008). The researchers of the Sector have fulfilled special works on the investigation of unusual gold forms in many deposits of the Urals and Siberia, as well as abroad (Kazakhstan, Canada). The sampling of deposits and tailings was provided with enrichment of material in a special spiral separator, which ensured the extraction of gold particles up to $20 \mu \mathrm{m}$ in concentrate. Under laboratory conditions the concentrates were developed with application of different methods (sieving, separation in heavy liquid, magnetic and electro-magnetic separation, treatment with $\mathrm{HCl}$, etc.). Fine gold particles of unusual forms were chosen under a binocular microscope for a more detailed study. Among fine gold particles (usually less than $50 \mu \mathrm{m}$ ) grains of globular structure were found. They had several levels of round gold aggregates: usually $20-10 \mu \mathrm{m}, 1-2 \mu \mathrm{m}$, and 200-300 $\mathrm{nm}$. The last were composed of nanoaggregates $(100-50 \mathrm{~nm})$, nanoparticles $(50-10 \mathrm{~nm}$ and less) and their combinations. Microprobe analysis showed that the average chemical composition of nanoparticles composing a grain up to $1 \mu \mathrm{m}$ in size was distinguished by the constant presence of mercury. Some of the globules were composed of gold amalgams (average $\mathrm{Hg}$ percentage exceeded 20 wt. \%). Thus, the processes of natural or technogenic amalgamation played the main role in the origin of this globular gold (Osovetsky, 2012, 2013, 2016a; Naumov, Osovetsky, 2013; Badyanova, 2015).

Another group of gold particles had a structure with two zones. The internal zone was presented by usual placer gold; the external one was composed by aggregates of microparticles with colloidal, star-like, etc. forms. High-resolution electron microscopy 
showed that such aggregates were the "new" nanogold growths on the surface of placer gold (Fig. 1).
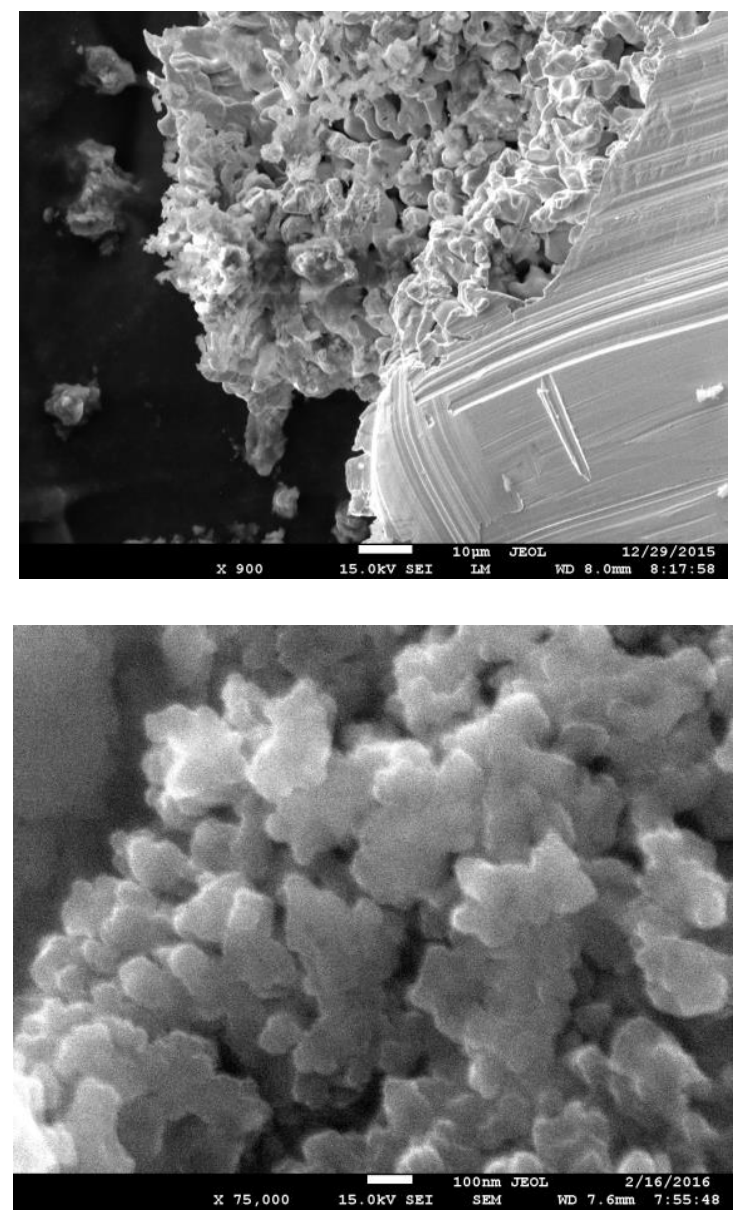

Fig. 1. The "new" growths on the surface of the Urals placer gold: at the top - a contact zone, at the bottom - the structure of growths at the nanolevel

There are several phases that differ in their chemical composition (first of all, metallic and intermetallic compounds of $\mathrm{Au}$, $\mathrm{Ag}, \mathrm{Cu}, \mathrm{Hg}, \mathrm{Pb}$, and complex goldferriferous, gold-silicon, gold-aluminum mixtures).

Platinum metals. The objects of study were platinum grains from placers of the Urals (Osovetsky, Barannikov, 2014). Highresolution electron microscopy showed the peculiarities of their internal structure, which included the signs of layering, fibrous or granular elements and fissures. For example, the fibrous elements up to $300 \mathrm{~nm}$ wide were found in platinum with admixture of palladium from the Ekatherininskaya placer (Fig.
2). The granular structure was a typical peculiarity of platinum too. A lot of elements corresponded to defects in the crystal lattice.

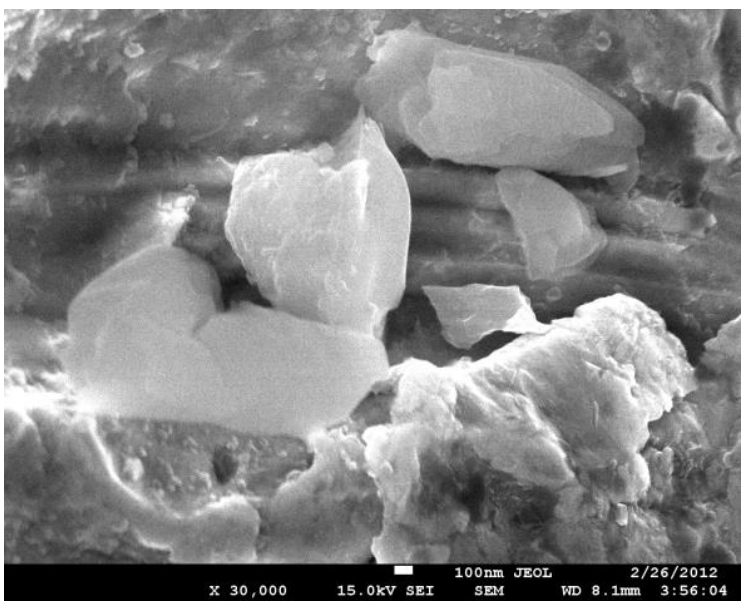

Fig. 2. Fibrous structural elements in a platinum grain

Fine diamonds. Nanolayering is the usual peculiarity of internal structure for fine diamonds (the objects of study are the fine grains from the Urals placers and kimberlites of Yakutia up to $1 \mathrm{~mm}$ and less in size). For example, nanolayers about $30 \mathrm{~nm}$ thick were found in some cubic crystals. There were carbon particles of up to $100 \mathrm{~nm}$ in size in a cover of coated diamonds (Fig. 3; Osovetsky, Naumova, 2014).

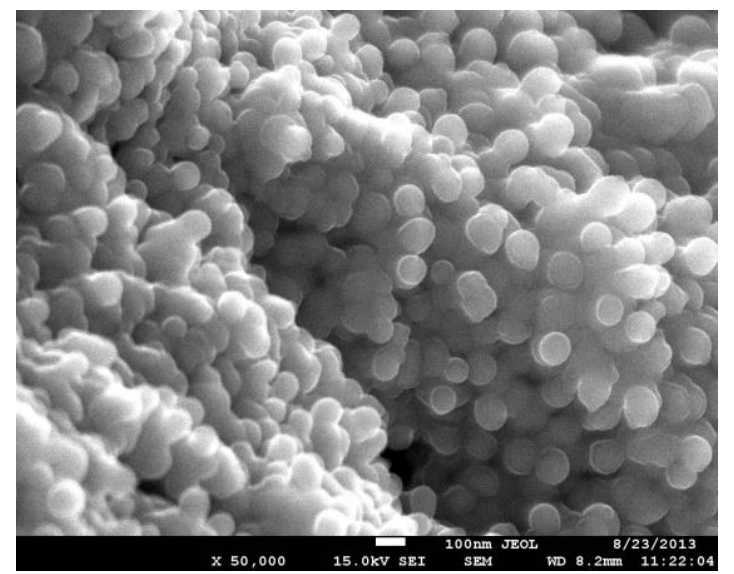

Fig. 3. Carbon particles in a cover of coated diamond

Surface nanotextures. The methods of high-resolution electron microscopy opened the new directions of mineral surface study at the nanolevel. The presence of great diversity 
of superficial nanodefects (cracks, pores, caverns, scratches, etc.) reflects the active influence of environmental factors (Fig. 4). On the other hand, they point to the peculiarities of mineral internal structure (nanolayering, nanograined structure, defects of crystal lattice, etc.).

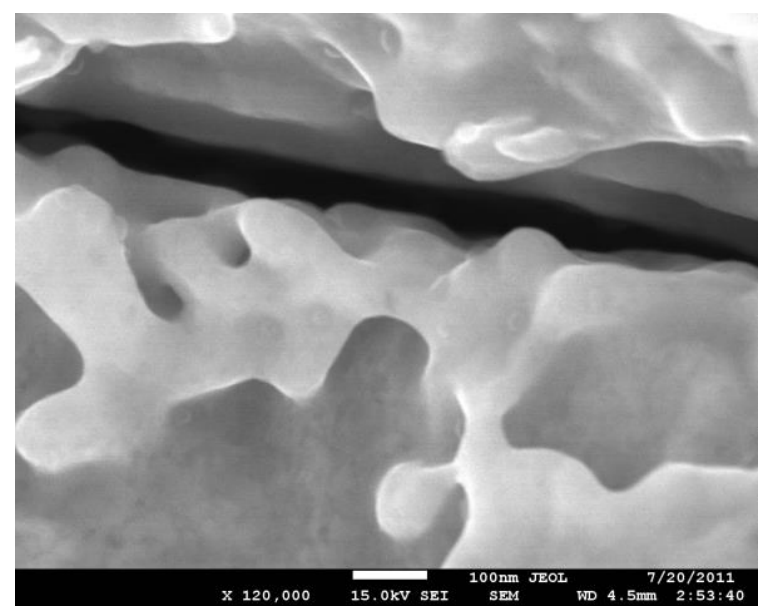

Fig. 4. Nanocrack on the surface of placer gold

Experiments. The experiments on precipitation of gold from solution on the surface of placer gold and activated coal, which were conducted by the Sector's staff, showed that metal had appeared on the surface as nanoparticles or their aggregates (Fig. 5).

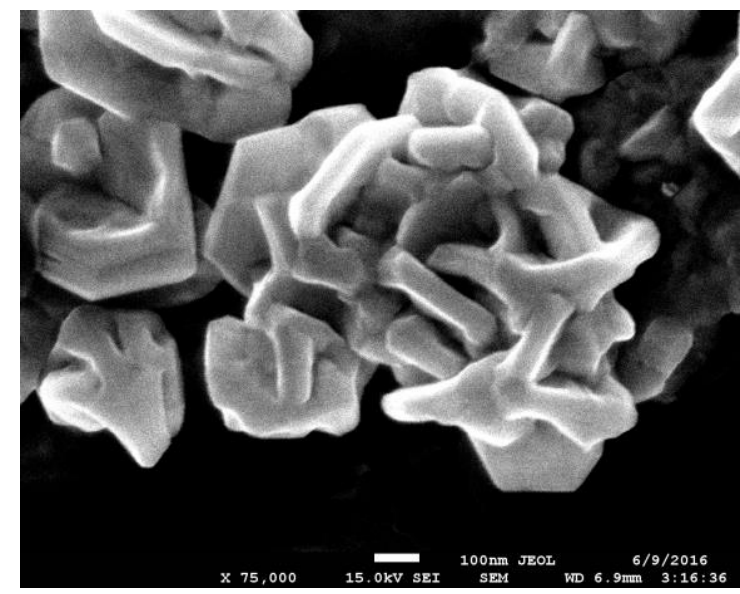

Fig. 5. Nanogold aggregates on the surface of natural placer gold (experiment)

The results of investigation testify to the widespread occurrence of the processes of spontaneous aggregation of nanogold particles in nature. These processes result in the enlargement of the metal particles with the formation of micrograins, which can be extracted with the use of modern technologies.

Natural nanotechnologies. The processes of nanogold aggregation may be regarded as natural nanotechnologies. They are the analogs of modern technologies in gold extraction applied for the purpose of merging its particles and ensuring their enlargement before enrichment with the use of gravitational methods. First of all, they deserve a special study in natural geological objects. Then, special experiments under the laboratory and natural conditions should be conducted. The positive results of such works may help to improve the technologies of gold extraction from ores in future (Osovetsky, 2016b; Osovetsky et al., 2016).

\section{References}

Badyanova I.V. 2015. Globulayrnoe zoloto chyornoslantsevykh tolshch [Globular gold of black shales]. Geology and Mineral Resources of the Western Urals. Perm Univ., Perm, pp. 3-5.

Hough R.M., Noble R.R.R., Hitchen G.J. et al. 2008. Naturally occurring gold nanoparticles and nanoplates. Geology. 36(7): 571-574.

Naumov V.A., Osovetsky B.M. 2013. Mercurious gold and amalgams in Mesozoic-Cenozoic rocks of the Vjatka-Kama Depression. Lithology and Mineral Resources. 48: 237-253.

Osovetsky B.M. 2012. Nanoskulptura poverkhnosti zolota [Nanosculpture of gold surface]. Perm University Press, Perm. 232 p. (in Russian).

Osovetsky B.M. 2013. Prirodnoe nanozoloto [Natural nanogold]. Perm University Press, Perm. 176 p. (in Russian).

Osovetsky B.M. 2016a. Aggregation of nanogold particles in the environment. Natural Resources Research. 25(2): 241-253.

Osovetsky B.M. 2016b. "Novoe" zoloto ["New" gold]. Perm University Press, Perm. 116 p. (in Russian).

Osovetsky B.M., Barannikov A.G. 2014. Surface of placer platinum under the electron microscope. Abstr. 12 $2^{\text {th }}$ Intern. Platinum Symp. Yekaterinburg, pp. 309-310.

Osovetsky B.M., Naumova O.B. 2014. Melkie almazy i ikh poiskovoe znachenie [Fine diamonds and their prospecting significance]. 
Perm University Press, Perm, 142 p. (in Russian).

Osovetsky B.M., Naumova O.B., Naumov V.A.

2016. Natural Processes of Nanogold Con- centration. $16^{\text {th }}$ Intern. Multidisciplinary Sci. GeoConf. (SGEM). Book 6, vol. III, pp. 105112.

\section{Достижения в наноминералогии}

\section{Б.М. Осовецкий}

Пермский государственный национальный исследовательский университет, Сектор наноминералогии, 614990, Пермь, ул. Букирева, 15

E-mail: opal@psu.ru

Представлены основные достижения в области наноминералогии, полученные сотрудниками Сектора наноминералогии за последние 5 лет (2012-2016). Они включают результаты исследований с применением высокоразрешающей электронной микроскопии с микрозондовым анализом и экспериментальные данные. Объектами изучения являлись необычные зерна россыпного золота Урала, Сибири (Россия), Казахстана и Территории Юкон (Канада). Основные выводы сводятся к доказательству активного проявления природных процессов агрегации наночастиц золота, которые приводят к образованию глобулярного и «нового» золота с укрупнением его зерен. Данные процессы могут быть использованы в современных технологиях извлечения золота из руд.

Ключевые слова: нанозолото, электронная микроскопия, агрегаџия, технология.

\section{Библиографический список}

Бадьянова И.В. Глобулярное золото черносланцевых толщ // Геология и полезные ископаемые Западного Урала. 2015. С. 35.

Наумов В.А., Осовеиякий Б.М. Ртутистое золото и амальгамы в мезокайнозойских породах Вятско-Камской впадины // Литология и полезные ископаемые. 2013. № 3. С. 256-273.

Осовецкий Б.М. Наноскульптура поверхности золота / Перм. гос. ун-т. Пермь, 2012. 232 c.

Осовецикий Б.М. Природное нанозолото / Перм. гос. ун-т. Пермь, 2013. 176 с.

Осовеикий Б.М. «Новое» золото / Перм. гос. ун-т. Пермь, 2016. 116 с.
Осовеикий Б.М., Наумова О.Б. Мелкие алмазы и их поисковое значение / Перм. гос. ун-т. Пермь, 2014. 142 с.

Hough R.M., Noble R.R.R., Hitchen G.J. et al. Naturally occurring gold nanoparticles and nanoplates // Geology. 2008. Vol. 36(7). P. 571-574.

Osovetsky B.M. Aggregation of nanogold particles in the environment // Natural Resources Research. 2016. Vol. 25 (2). P. 241-253.

Osovetsky B.M., Barannikov A.G. Surface of placer platinum under the electron microscope // Abstr. 12 ${ }^{\text {th }}$ Intern. Platinum Symp. Yekaterinburg, 2014. P. 309-310.

Osovetsky B.M., Naumova O.B., Naumov V.A. Natural Processes of Nanogold Concentration $/ / 16^{\text {th }}$ Intern. Multidisciplinary Sci. GeoConf. (SGEM). 2016.Book 6, vol. III. P. 105-112. 